\title{
DEMOCRATIZING CRIMINAL LAW: FEASIBILITY, UTILITY, AND THE CHALLENGE OF SOCIAL CHANGE
}

\author{
Paul H. Robinson
}

\begin{abstract}
There are good reasons to be initially hesitant about shaping criminal law rules to track the justice judgments of ordinary people. People seem to disagree about many criminal law issues. Their judgments, at least as reflected in many aspects of current law such as three strikes and high penalties for drug offenses, seem harsh to many. Effective crime control would seem to require the expertise of trained experts and scholars who understand the complexities of general deterrence and the identification and incapacitation of the dangerous.

But this brief Essay, which reviews some previous studies and analyses, argues that distributing criminal liability and punishment according to the shared judgments of the community-so-called "empirical desert"- does not have the failings that many assume, such as those described above, and indeed ought to be preferred by both moral philosophers and crime-control utilitarians. It represents the best practical approximation of deontological desert. And it offers the greatest potential for effective crime control because, by tracking community views, the criminal law can build its moral credibility with the community and thereby harness the potentially enormous powers of social influence and internalized norms.
\end{abstract}

AUTHOR - Colin S. Diver Professor of Law, University of Pennsylvania Law School. Many thanks to Joshua Kleinfeld, Rick Bierschbach, and the editors of the Northwestern University Law Review. 


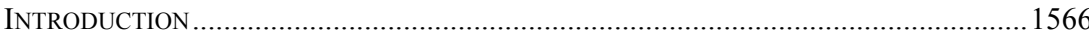

I. Is There Any Such Thing AS the Community's Views of Justice? .................1567

II. ARE the Community's Views of Justice Brutish AND Draconian?...............1574

III. Why Should the Criminal Law Care What the Community Thinks Is JuST? .

IV. Should the Criminal Law Ever Deviate from the Community's Shared JUDGMENTS OF JUSTICE? 1588

CONCLUSION 1594

\section{INTRODUCTION}

The notion of "democratizing criminal law" has an initial appeal because, after all, we believe in the importance of democracy and because criminal law is so important-it protects us from the most egregious wrongs and is the vehicle by which we allow the most serious governmental intrusions in the lives of individuals. Given criminal law's special status, isn't it appropriate that this most important and most intrusive governmental power be subject to the constraints of democratic determination?

But perhaps the initial appeal of this grand principle must give way to practical realities. As much as we are devoted to democratic ideals, perhaps the path to a better society is one that must recognize inherent weaknesses in the system of democratic action, which necessarily relies upon the judgments of common people. Perhaps, when dealing with things as important as doing justice and preventing crime, we must look instead to experts, such as criminologists and moral philosophers. Perhaps the path to a better society is one that, in this instance, should skirt democratic preferences as needed?

More specifically, consider some of the realities that might derail a movement toward democratizing criminal law. First, perhaps there is no such thing as a shared community view of justice on which to base a system of criminal law, but simply an endless list of individual disagreements. There can be no such thing as a criminal code that reflects community views if there is no such thing as a shared community view. Second, even if there were a shared community sense of justice, perhaps that view is something born of anger and suspicion, brutish and draconian, and something that even the people themselves feel should not be publicly enshrined in principles of liability and punishment. Third, even if community views of justice are in fact enlightened, perhaps they do not achieve a more pervasive goal of reducing crime. That is, perhaps the path to effective crime control is not through justice-either the community's 
view of it or the moral philosopher's view-but through more instrumentalist crime-control mechanisms, such as general deterrence or incapacitation of the dangerous. And finally, even if relying upon the community's views of justice was an effective crime-control mechanism, wouldn't such a system condemn us to live under the status quo of current community views? History teaches us that a society can improve itself and the lives of its members only by moving ever forward in refining its judgments of justice.

Thus, this brief Essay will take up these four questions: (1) Is there any such thing as the community's views of justice? (2) Are the community's views of justice brutish and draconian? (3) Why should a criminal law concerned with crime-control care what the community thinks is just? (4) Should criminal law ever deviate from the community's shared judgments of justice?

\section{Is THERE ANy SUCH THING AS THE COMMUNITY'S VIEWS OF JUSTICE?}

Given the subjective and complex nature of judgments about justice, one would expect disagreement among people. But the research suggests otherwise. It shows a high degree of agreement about judgments of justice across all demographics, at least for what one might call the core of wrongdoing - physical aggression, taking property without consent, and deceit in exchanges. As potential crimes move out from this core, the judgments become culturally dependent, and thus more diverse. ${ }^{1}$

The high level of agreement seen is not agreement on the exact punishment that should be imposed in any particular case, but rather is agreement on the relative blameworthiness of different offenders, a rankordering of cases according to the punishment they deserve. People and societies will disagree about the severity of punishment to impose. Different people may want to set a different high-end point on the punishment continuum. Some may set the high-end point as the death penalty; others may set it at life imprisonment, while still others may set it at ten years' imprisonment. The high-end point is a culturally dependent determination and is thus malleable. But once the high-end point is set, as it must be in every society, people commonly will agree where on the punishment continuum a given case falls for the amount of punishment deserved.

\footnotetext{
${ }^{1}$ For a more detailed discussion of these issues and the studies cited infra notes 2-6, see PAUL H. Robinson, INTUITIONS OF JUSTICE AND the UtiLity OF DESERT ch. 2 (2013) [hereinafter ROBINSON, IJUD].
} 
In one study, for example, subjects were asked to rank order twentyfour scenarios describing a criminal event according to their proper level of punishment. Each story described a particular course of potentially wrongful conduct for a wide range of offenses, from minor assault or theft to serious wrongdoing such as robbery or murder. The results showed that essentially all subjects ranked the twenty-four scenarios the same, with agreement across all demographics. That is, the results were not affected by the subject's gender, age, level of education, political views, race, marital status, religion, income, or any other typically influential demographic.

Strikingly, the level of agreement measured by Kendall's W (a coefficient of concordance in which 1.0 means perfect agreement) was 0.95 among subjects tested in person and 0.88 among subjects tested on the internet. As a point of comparison, in a study of American men ranking the beauty of women with different waist-to-hip ratios, the researchers found a Kendall's W of $0.54 .^{2}$ A study of travel magazine readers ranking destinations by danger of terrorism found a Kendall's W of $0.52 .^{3}$ Economists ranking the top twenty economic journals by quality had a Kendall's W of $0.095 .{ }^{4}$

Indeed, to get a Kendall's W as high as this judgments-of-justice study, one must look to what are close to pure perceptual tasks. For example, in one study, subjects were asked to judge the overall relative brightness of different clusters of differently shaded dots. Subjects generally agreed in their rankings, with a Kendall's W of $0.95 .^{5}$ In another study, researchers tested the seven faces you see below, showing different levels of discomfort. These are the faces used by doctors to get pain level information from patients who are too young to speak, or who do not speak the doctor's language. Subjects typically agreed when asked to rank the images according to the amount of pain they showed, with a Kendall's W of $0.97 .^{6}$

\footnotetext{
${ }^{2}$ Frank Marlowe \& Adam Wetsman, Preferred Waist-to-Hip Ratio and Ecology, 30 PersonAlity $\&$ INDIVIDUAL DIFFERENCES 481, 483 (2001).

${ }^{3}$ Baruch Fischhoff, Wändi Bruine De Bruin, Wendy Perrin \& Julie Downs, Travel Risks in a Time of Terror: Judgments and Choices, 24 RISK ANALYSIS 1301, 1303 (2004).

${ }^{4}$ Kostas Axarloglou \& Vasilis Theoharakis, Diversity in Economics: An Analysis of Journal Quality Perceptions, 1 J. EUROPEAN ECON. ASs'N 1402, 1421-22 (2003).

${ }^{5}$ Charles M M de Weert \& Noud A W H van Kruysbergen, Assimilation: Central and Peripheral Effects, 26 PERCEPTION 1217, 1221 (1997).

${ }^{6}$ Keela A. Herr, Paula R. Mobily, Frank J. Kohout \& Diane Wagenaar, Evaluation of the Faces Pain Scale for Use with the Elderly, 14:1 Clinical J. PAIN 29, 29 (1998), http://journals.lww.com/pain/fulltext/10.1016/0304-3959(90)90018-9. Figure 1, also known as the Faces Pain Scale, originated in a 1990 study. Davia Bieri, Robert A. Reeve, G. David Champion, Louise Addicoat \& John B. Ziegler, The Faces Pain Scale for the Assessment of the Severity of Pain
} 


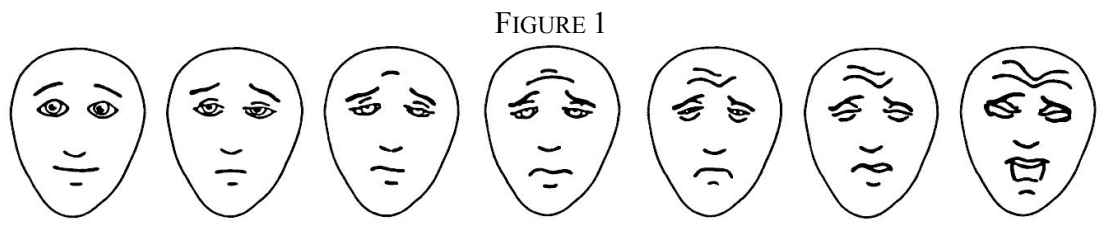

Important here is the fact that there is not an infinite number of meaningfully different points on a punishment continuum. The meaningfully different punishment units become larger as the punishment amount increases. The difference between sentences of three days and seven days is meaningful to people, but the difference between a sentence of ten years and three days versus ten years and seven days is not seen as meaningful different. The higher on the punishment continuum, the larger the meaningful punishment units. Thus, the number of meaningfully different punishment units on the punishment continuum is limited.

Yet, the number of cases that people will see as meaningfully different in the punishment deserved is very high. That is, each case requires a specific amount of punishment, not just a general range of punishment. There is not some magical connection between an offense and an amount of punishment. Rather, the specific amount of punishment required is an amount of punishment that will put that offense in its proper ordinal rank.

This helps explain why it has taken us so long to discover the high level of agreement on the relative seriousness of different core wrongs. People's disagreements about general severity of punishment - such as their disagreement about the proper high-end point of the punishment continuum-obscured their common agreement on relative blameworthiness. $^{7}$

People commonly have a quick answer to such questions as "Should someone be punished for what they have done?" and "If so, what is the relative blameworthiness of this offender and offense as compared to other offenses?" The answers could be the result of reasoning-thinking carefully through the issue and applying some set of principles. However, for many, these answers are intuitional rather than reasoned. That is, these answers come to them without logically thinking through steps in applying principles. Instead, they arrive at an answer almost as if they were observing it as a fact.

As the Kahneman graphic depicts below, intuitions have much in common with pure perception. Intuitions produce answers that are fast,

Experienced by Children: Development, Initial Validation, and Preliminary Investigation for Ratio Scale Properties, 41:2 PAIN 139, 144 (1990), http://journals.lww.com/clinicalpain/toc/1998/03000.

${ }^{7}$ For a more detailed discussion of these issues, see RoBINSON, IJUD, supra note 1, at ch. 2. 
automatic, and effortless. The speed of intuitions is quite different from the speed of reasoning, which tends to be slow, controlled, and effortful. What is so striking, and so interesting, about intuitions is that unlike perceptions, which typically deal with very simple, objective things, intuitions can concern complex and conceptual things, which typically are the subject of reasoning. ${ }^{8}$

FiguRE 2

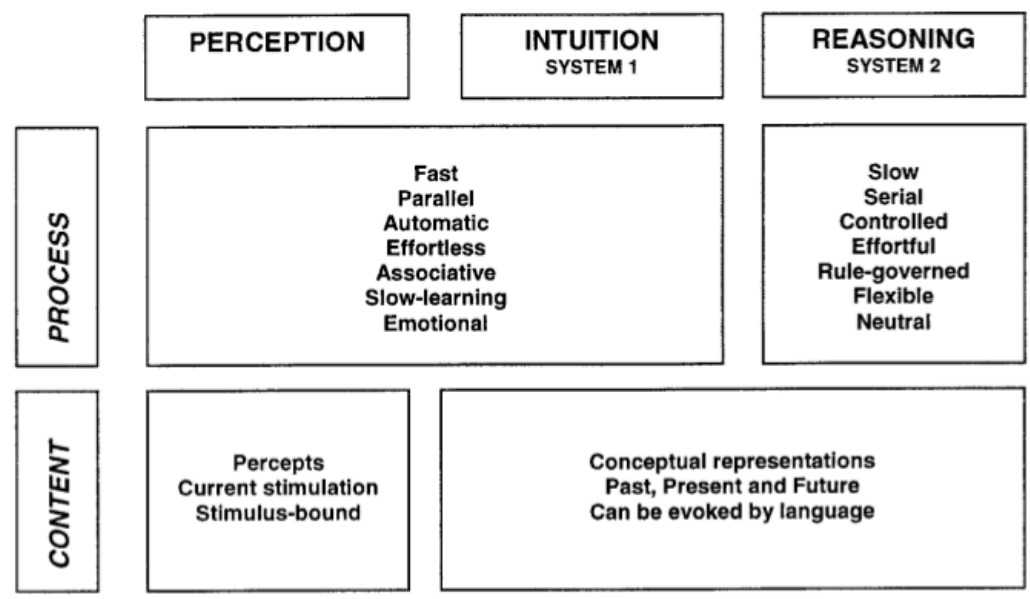

Intuitions of justice are a good example. Judgments about justice seem complex and subtle, yet when they are intuitional, people arrive at them quickly and effortlessly. Further, people have no access to why they came to an intuitive conclusion. Unlike a reasoned conclusion, where they understand and remember the series of steps that brought them to that conclusion, intuitions seem obvious to them-so obvious as to not require an explanation. Educated people in particular, who might pride themselves on being rational, will commonly make up reasons after the fact to explain and give the appearance of rationality to their intuitive judgments. But these reasons are not how they reached their respective intuitive conclusions; they are only an attempt to justify them. ${ }^{9}$

What is perhaps most striking about people's justice judgments is that they are quite nuanced and sophisticated. Small changes in facts can produce large and predictable changes in liability judgments. Yet

\footnotetext{
${ }^{8}$ Figure 2 was originally produced in Daniel Kahneman, A Perspective on Judgment and Choice Mapping Bounded Rationality, 58 AM. PsYchologist 697, 698 (2003). Reprinted with permission from the American Psychological Association (APA). For a more detailed discussion of these issues, see RoBINSON, IJUD, supra note 1, at 6-7.

${ }^{9}$ For a more detailed discussion of these issues, see ROBINSON, IJUD, supra note 1, at ch. 1.
} 
sophistication does not depend upon education, intelligence, or upon other demographic factors. Research has repeatedly shown this to be true in a wide range of criminal law contexts. Examples of this are found in the following areas: the objective requirements of complicity; attempt; causation; offense culpability doctrines such as mistake, accident, voluntary intoxication, and the partial individualization of the reasonable person standard for negligence; justification doctrines such as defensive force and law enforcement use of force; culpability requirements; excuse doctrines such as insanity, immaturity, involuntary intoxication, duress, and entrapment; grading doctrines such as those relating to sexual offenses and homicide offenses; testing empirical claims of theoretical literature; and using individualized judgments to test competing scholarly theories, such as the nature of justification defenses, blackmail, and the nature of the shift from common law to modern penal codes. ${ }^{10}$

This picture of laypersons' judgments of justice-high levels of agreement on the relative blameworthiness of many aspects of the core wrongdoing, the apparently intuitional nature of many aspects of these judgments, and the high level of nuance and sophistication-may seem a bit puzzling. What can possibly explain why we are built this way?

One theory, supported by a good deal of evidence, suggests that this aspect of human nature results from pressures of evolutionary development. Early human groups on the Serengeti Plain were surrounded by bigger, faster, and stronger predators. What saved them-what made humans the most successful species in the history of the planet-was the ability they developed for cooperative action. To maintain cooperative action, a group must have certain foundational rules of conduct among members. The "core of wrongdoing" so universally agreed upon across demographics seems a good candidate for these foundational rules: no physical aggression against other group members, no taking of another's property without consent, and no deceit in exchanges. To allow such victimization would be to risk undermining the cooperation of the group member being victimized.

But the rules mean nothing without enforcement, so a system of punishment for violating the foundational rules must exist to maintain a desired level of cooperation. Complicating things is the fact that the only available methods of punishment seem themselves to be violations of the basic prohibitions: beating a violator, or taking his possessions, or depriving him of his share of the group's food. Thus, the group members had to appreciate the existence and special status of punishment for

\footnotetext{
${ }^{10}$ For more details, see ROBINSON, IJUD, supra note 1, and infra Parts III-IV.
} 
violation, and to develop some kind of shared understanding of what constituted a violation and what constituted appropriate punishment for it. The propriety of punishing wrongdoing and the notion of proportionality between the seriousness of the violation and the seriousness of the punishment are the foundational principles upon which laypersons of today tend to agree. It would seem to fit nicely with the demands of the punishment system among the early human groups on the Serengeti Plain. The groups that can develop and maintain such shared understandings can most effectively maintain their cooperative nature and will flourish. The groups that cannot do so will lose their cooperative nature and die out. ${ }^{11}$

Humans are not the animals who created the notion of cooperative action, the institution of punishment, and the principle of proportionality. Rather, the 125,000 generations of humans were simply building on the foundation of those principles established by their evolutionary ancestors. More rudimentary forms of the same notions can be seen in the conduct of many animal species, especially those that show cooperative social structures. $^{12}$ Also support for the notion of a partially innate human predisposition toward these principles is found in the child development literature. Most striking here is that social scientists can identify a predictable pattern of moral development that is quite detailed-predicting specific stages of development at specific ages - that is seen in every known human society on the planet and is immune to demographic differences. ${ }^{13}$

Given the enormous influence of one's life experience, be it one's culture, gender, education, socioeconomic status, race, religion, or any number of other influential demographic variables, how could it be that despite these dramatic differences there can exist such human universals? That such universals do exist illustrates the power of their influence and supports the notion that there is a partially innate human predisposition at work. That predisposition no doubt can play out in different waysconditions of starvation, as opposed to conditions allowing one to earn a $\mathrm{Ph} . \mathrm{D}$. in economics, may influence how the predisposition develops-but there is every reason to believe that there exists a shared core that is part of the human character.

Interestingly, we see common patterns of conduct and attitudes in relation to judgments of justice even in the most extreme situations.

\footnotetext{
11 For a more detailed discussion, see RoBINSON, IJUD, supra note 1, at 36-41.

12 For a more detailed discussion, see ROBINSON, IJUD, supra note 1, at ch. 3. For a more popular presentation of these issues, see PAUl H. RoBINSON \& SARAH M. ROBINSON, PIRATES, PRISONERS, AND LEPERS: LESSONS FROM LIFE OUTSIDE THE LAW chs. 2-4 (2015).

13 For a more detailed discussion of these issues, see ROBINSON, IJUD, supra note 1, at 48-54.
} 
Examining a host of natural experiments over the past century or two in which human groups were thrust into a situation where government and law could no longer have an effect on them, we still see evidence of the human predisposition toward shared views of wrongdoing and punishment across a staggeringly varied set of absent-law situations. These natural experiments include plane crashes, shipwrecks, forced leper colonies, goldmining camps, pirate colonies, inmates in prison camps, prisoners after an uprising, residents of occupied territory in war, and a host of other absentlaw situations. ${ }^{14}$

All of this is not to suggest that there is agreement on all criminal liability and punishment rules. There is not. As noted above, while people may agree on the relative seriousness of many aspects of core wrongdoings, they disagree on other issues. Also, the further out from the core, the greater disagreement can be. Further out from the core, the ultimate judgment increasingly depends upon a larger measure of reasoned judgment extrapolating from an initial intuition, and is more influenced by cultural or other demographic variables. But the larger point is that, contrary to the once common wisdom, justice judgments are not all matters on which everyone disagrees about everything. Some universal principles do exist, which means that one can reasonably speak of a core of a "community view."

In my discussion of the third question of this Essay, I will come back to the issue of the existence of disagreements on some issues. The significance of points of disagreement depends in part upon whether and why one cares about community views in the first place.

Assuming that there is a community view of justice, if we are to move beyond academic discussion to the practical realities of lawmaking, we must face the possibility that different communities have somewhat different views on some criminal law matters. Thus, we must be able to answer the question, "Which community?" But the answer to that is simple, even obvious: the relevant community is that which will be bound by the rule being enacted. If the issue is how to construct a state criminal code, then the relevant community is the residents of that state. If the issue is the provision of a municipal code, the relevant population is the residents of that city. If the issue arises in the federal criminal code, the relevant population is all U.S. residents.

To summarize, research suggests there is a high degree of agreement among people at least in regard to crimes that are the core of wrongdoing. In addition, while people may disagree as to the exact punishment that

\footnotetext{
${ }^{14}$ See generally ROBINSON \& ROBINSON, PIRATES, supra note 12.
} 
should be imposed, they generally agree as to the relative severity of punishment that should be given based on the relative severity of the offense. Therefore, it seems at least a colorable community view of justice exists. This brings us to our second question, which is whether this community view of justice may be draconian and brutish.

\section{ARE THE COMMUNITY'S VIEWS OF JUSTICE BRUTISH AND DRACONIAN?}

One might conclude that there is such a thing as the community view of justice yet be appalled at the notion that a society should give deference to this view given the practical evidence on display about where such deference would take us. Consider some of the politically popular criminal law doctrines common in the United States: (1) the "three strikes" statutes, which can provide long prison terms for an offender who has previous criminal convictions, (2) high penalties for drug-related offenses, (3) rules reducing the age at which an offender can be prosecuted as an adult, (4) rules narrowing or eliminating the insanity defense, (5) the use of "strict liability" offenses, which do not require that the offender had a culpable state of mind toward the conduct and circumstances of the offense, and (6) the "felony murder rule," which provides that anyone causing a death even accidentally during the commission of a felony is liable for murder, the most serious form of homicide otherwise reserved for intentional killings.

It may be no surprise that people commonly assume that such criminal law doctrines reflect community views, given that we are living in a democracy. But that assumption turns out to be wrong. Consider a recent study that tested laypersons' judgments of justice on the six illustrative doctrines listed above. Subjects were given a dozen "milestone scenarios" that previous testing had shown represented the full spectrum of relative blameworthiness. These scenarios presented cases from something as trivial as mistakenly taking another person's umbrella at a restaurant to intentionally killing another person in an ambush. Subjects were also given a dozen scenarios, each based on a real-world case, that involve one of the six crime-control doctrines above. Those "crime-control scenarios" are summarized on the table below. ${ }^{15}$

\footnotetext{
15 This table is reproduced from ROBINSON, IJUD, supra note 1, at 123. For additional information on this study, see Paul Robinson, Geoffrey P. Goodwin \& Michael D. Reisig, The Disutility of Injustice, 85 N.Y.U. L. REV. 1940 (2010).
} 
TABLE 1

\begin{tabular}{|c|c|c|c|c|}
\hline Scenario & Case Name & Offense & $\begin{array}{c}\text { Crime-Control } \\
\text { Doctrine }\end{array}$ & $\begin{array}{c}\text { Actual Court } \\
\text { Sentence } \\
\end{array}$ \\
\hline $\begin{array}{l}\text { L. Accidental } \\
\text { teacher shooting }\end{array}$ & Brazill & Murder & $\begin{array}{c}\text { Adult Prosecution } \\
\text { of Juveniles }\end{array}$ & $\begin{array}{l}28 \text { years w/o } \\
\text { parole }\end{array}$ \\
\hline $\begin{array}{l}\text { K. Drowning } \\
\text { children to save } \\
\text { them from hell }\end{array}$ & Yates & Murder & $\begin{array}{c}\text { Narrowing } \\
\text { Insanity Defense }\end{array}$ & life \\
\hline $\begin{array}{l}\text { J. Accomplice } \\
\text { killing during } \\
\text { burglary }\end{array}$ & Moore & $\begin{array}{l}\text { Felony murder, } \\
\text { burglary }\end{array}$ & Felony Murder & $\begin{array}{l}\text { life at hard labor } \\
\text { w/o parole }\end{array}$ \\
\hline $\begin{array}{l}\text { I. Killing officer } \\
\text { believed to be } \\
\text { alien }\end{array}$ & Clark & Murder & $\begin{array}{c}\text { Narrowing } \\
\text { Insanity Defense }\end{array}$ & life \\
\hline $\begin{array}{l}\text { H. Cocaine } \\
\text { overdose }\end{array}$ & Heacock & $\begin{array}{c}\text { Felony murder, } \\
\text { unlawful } \\
\text { distribution of } \\
\text { controlled } \\
\text { substance } \\
\end{array}$ & Felony Murder & 40 years \\
\hline $\begin{array}{l}\text { G. Cocaine in } \\
\text { trunk }\end{array}$ & Harmelin & $\begin{array}{l}\text { Complicity in } \\
\text { unlawful } \\
\text { distribution of } \\
\text { controlled } \\
\text { substance } \\
\end{array}$ & $\begin{array}{c}\text { Drug Offense } \\
\text { Penalties }\end{array}$ & life w/o parole \\
\hline $\begin{array}{l}\text { F. Air conditioner } \\
\text { fraud }\end{array}$ & Rummel & Petty fraud & Three Strikes & life w/o parole \\
\hline $\begin{array}{c}\text { E. Sex with female } \\
\text { reasonably } \\
\text { believed overage }\end{array}$ & Haas & Statutory rape & Strict Liability & 40 to 60 years \\
\hline $\begin{array}{l}\text { D. Underage sex } \\
\text { by mentally } \\
\text { retarded man }\end{array}$ & Garnett & Statutory rape & Strict Liability & 5 years \\
\hline $\begin{array}{l}\text { C. Marijuana } \\
\text { unloading }\end{array}$ & Papa & $\begin{array}{c}\text { Unlawful } \\
\text { possession of } \\
\text { controlled } \\
\text { substance }\end{array}$ & $\begin{array}{c}\text { Drug Offense } \\
\text { Penalties }\end{array}$ & 8 years \\
\hline B. Shooting of TV & Almond & $\begin{array}{c}\text { Unlawfully } \\
\text { discharging } \\
\text { firearm } \\
\end{array}$ & Three Strikes & $\begin{array}{c}15 \text { years w/o } \\
\text { parole }\end{array}$ \\
\hline $\begin{array}{c}\text { A. Incorrect } \\
\text { lobster container }\end{array}$ & Blandford & $\begin{array}{l}\text { Violation of } \\
\text { importation } \\
\text { regulations }\end{array}$ & $\begin{array}{c}\text { Criminalizing } \\
\text { Regulatory } \\
\text { Violations }\end{array}$ & 15 years to life \\
\hline
\end{tabular}


Subjects were asked to rank order all two dozen cases and to give an appropriate sentence to each. The results are summarized in Table 2 below. ${ }^{16}$ The numbered cases on the left-hand margin are the milestone scenarios. The indented and lettered italicized cases are the crime-control scenarios.

TABLE 2

\begin{tabular}{|c|c|c|}
\hline Scenario & $\begin{array}{c}\text { Subjects' Mean } \\
\text { Sentence } \\
\end{array}$ & $\begin{array}{c}\text { Actual Court } \\
\text { Sentence }\end{array}$ \\
\hline 12. Ambush shooting & $\begin{array}{l}\text { between life and } \\
\text { death }\end{array}$ & \\
\hline 11. Stabbing & essentially life & \\
\hline 10. Accidental mauling by pit bulls & 20.6 years & \\
\hline L. Accidental teacher shooting (juvenile) & 19.2 years & $\begin{array}{l}28 \text { years } w / o \\
\text { parole }\end{array}$ \\
\hline $\begin{array}{l}\text { K. Drowning children to save them from hell } \\
\text { (insanity) }\end{array}$ & 26.3 years & life \\
\hline $\begin{array}{l}\text { J. Accomplice killing during burglary (felony } \\
\text { murder) }\end{array}$ & 17.7 years & $\begin{array}{c}\text { life at hard labor } \\
\text { w/o parole }\end{array}$ \\
\hline 9. Clubbing during robbery & 12.0 years & \\
\hline 8. Attempted robbery at gas station & 9.1 years & \\
\hline I. Killing officer believed to be alien (insanity) & 16.5 years & life \\
\hline H. Cocaine overdose (felony murder) & 10.7 years & 40 years \\
\hline 7. Stitches after soccer game & 5.0 years & \\
\hline 6. Slap and bruising at record store & 3.9 years & \\
\hline G. Cocaine in trunk (drugs) & 4.2 years & life w/o parole \\
\hline F. Air conditioner fraud (three strikes) & 3.1 years & life $w / o$ parole \\
\hline 5. Microwave from house & 2.3 years & \\
\hline $\begin{array}{l}\text { E. Sex with female reasonably believed overage } \\
\text { (strict liability) }\end{array}$ & 2.9 years & 40 to 60 years \\
\hline 4. Clock radio from car & 1.9 years & \\
\hline $\begin{array}{l}\text { D. Underage sex by mentally retarded man (strict } \\
\text { liability) }\end{array}$ & 2.3 years & 5 years \\
\hline C. Marijuana unloading (drugs) & 1.9 years & 8 years \\
\hline B. Shooting of TV (three strikes) & 1.1 years & $\begin{array}{l}15 \text { years } w / o \\
\text { parole }\end{array}$ \\
\hline 3. Whole pies from buffet & 8.3 months & \\
\hline A. Incorrect lobster container (regulatory) & 9.7 months & 15 years to life \\
\hline 2. Wolf hallucination & 1.1 years & \\
\hline 1. Umbrella mistake & 1.8 months & \\
\hline
\end{tabular}

\footnotetext{
16 This table is reproduced from RoBINSON, IJUD, supra note 1, at 125. For additional information about this study, see Robinson et al., supra note 15.
} 
Below is a more graphic presentation of the information in Table $2 .{ }^{17}$ The cases on the left of the graphic are the milestone scenarios, which provide points of comparison along the full length of the punishment continuum. The lines from each case to the punishment scale show how severely the lay persons would punish each of these milestone offenses.

On the right are the cases illustrating the six common crime-control doctrines described above. The solid lines on the right show the amount of punishment that the study's subjects would impose in each case. The dotted lines show what punishment the law would impose, and did actually impose in the case. As you see, the law's punishment is dramatically higher than that of the study's subjects. The difference is even more striking when you take into account that the punishment continuum used here is exponential. That is, moving from 1 to 2 triples the punishment (from two months to six months), just as moving from 3 to 4 triples the punishment (from one year to three years). Thus, the large difference between the solid lines and the dotted lines for each case shows that the punishment the law imposes is commonly many times more severe than what the study's subjects would impose.

FIGURE 3

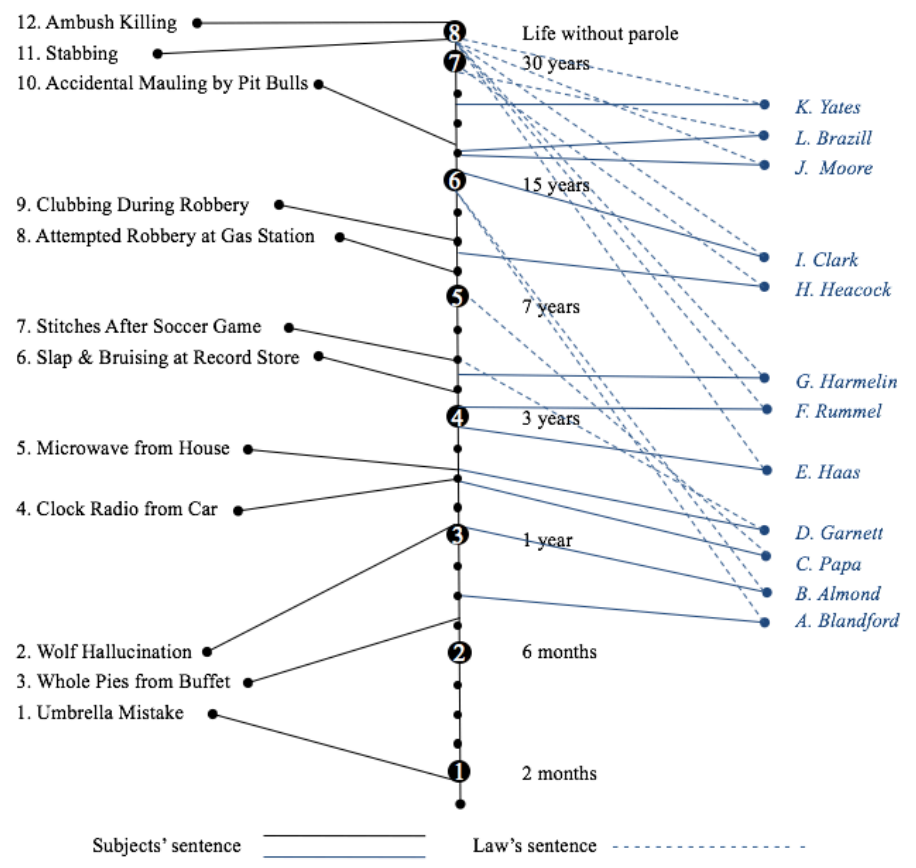

17 This figure is reproduced from RoBINSON, IJUD, supra note 1, at 127, and Robinson et al., supra note 15 , at 1973 . 
How could such a discrepancy occur in a democracy, where the laws are enacted by elected representatives of the people? The underlying causes of this phenomena are the operation of crime politics in the United States. First, politicians have been persuaded - often by academics - that they should focus on crime control without regard to its effect on deserved punishment. And second, politicians frequently use criminal law legislation for their own political purposes, rather than to do justice or prevent crime. ${ }^{18}$ Many amendments and new offenses are enacted to show constituents their concern for some headline issue. However, we cannot be too critical here. Politicians are simply trying to be responsive to their communitynormally something we see as a good thing, and usually a positive feature of democracy.

But in many instances, "the problem" about which some constituents or the local newspaper headlines are concerned has little to do with a flaw in an existing criminal law. Not every problem can be fixed with a criminal code amendment. People will continue to commit outrageous crimes, judges will continue to make what are seen as sentencing errors, and so on. Yet, legislators often feel a need to do something to show that they are sensitive to their constituents' concerns. And there are few "somethings" that they can do. Changing or adding to the criminal law is one of the few things available. But when crime legislation is simply a vehicle for expressing concern, drafters have few ways to assure that their legislation in fact improves rather than degrades criminal law, and justice, in the longer term.

Unfortunately, criminal law bills, even if useless and unnecessary, commonly pass because legislators commonly share a reluctance to appear "soft on crime." When a new and unnecessary offense, say "library theft," is proposed, the issue becomes a referendum on whether legislators care about public libraries, not on whether the proposed legislation will actually do anything new to combat the problem of such theft, or on whether it will instead have pernicious ramifications for the application of the criminal code's general theft provision. A legislator is likely to vote in favor of the library-theft bill because there is a clear constituency-library users and taxpayers - who would seem to share a concern about library theft, and no constituency to complain about the new provision's less obvious and more diffuse drawbacks in creating inconsistencies, ambiguities, and overlaps.

\footnotetext{
${ }^{18}$ For a more detailed discussion of these issues, see Paul H. Robinson \& Michael T. Cahill, The Accelerating Degradation of American Criminal Codes, 56 Hastings L.J. 633 (2005); Paul H. Robinson, The Rise and Fall and Resurrection of American Criminal Codes, 53 U. LOUISVILLE L. REV. 173 (2015).
} 
Another sort of systemic problem might be called "punishment inflation." In order to emphasize how seriously the legislators take the new offense they have created, the heat of the moment naturally pushes the grade of the offense higher than it might otherwise be. A year or two later, when that heat has died down, the grade may seem inconsistent with other offenses, but the exaggerated grade lives on.

Worse, the dynamic creates a vicious cycle. Having exaggerated the grade of yesterday's "crime du jour," the legislator, in order to adequately express outrage over today's crime $d u$ jour, must exceed the new, exaggerated baseline established by yesterday's offense. The ultimate effect is to create an upward spiral of grading, and a hodge-podge of inconsistent offense grades. There is no fixing this problem ad hoc. Internal grading consistency within a code requires examining all of its offense and suboffense grades at one time, comparing each against the grade of every other.

We see this unhealthy dynamic in every state that we have investigated. ${ }^{19}$ In Kentucky, for example, a relatively thoughtful criminal law reformer among the states, it is estimated that there are now 440 provisions in the criminal code and 1800 criminal offenses outside of the code. This is a dramatic increase over what existed when the new comprehensive criminal code was enacted in 1974. Yet new forms of criminal activity that did not exist in 1974 make up only a trivial number of these new offenses. ${ }^{20}$

It is possible to recodify current American criminal codes to better reflect the community's true judgments of justice and to better maintain that correspondence in the future. ${ }^{21}$ But the larger point here is that the

\footnotetext{
19 See, e.g., Paul H. Robinson et al., Report of the Delaware Criminal LaW RECODIFICATION PROJECT (2017), https://papers.ssrn.com/sol3/papers.cfm?abstract_id=2950728 [https://perma.cc/9FFM-U8MA]; PAUL H. ROBINSON ET AL., FinAl REPORT OF THE MALDIVES PENAL LAW AND SENTENCING CODIFICATION PROJECT (2006), http://ssrn.com/abstract=1522222 [https:// perma.cc/XT5A-KhS4]; Paul H. Robinson, Final Report of the Kentucky Penal Code REVISION PROJECT (2003), https://ssrn.com/abstract=1523384 [https://perma.cc/3EDQ-B42B]; PAUL H.

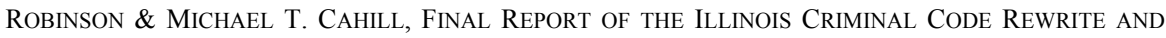
REFORM COMMISSION (2003), http://scholarship.law.upenn.edu/cgi/viewcontent.cgi?article= 1290\&context=faculty_scholarship [https://perma.cc/PK3C-83WW].

${ }^{20}$ Robinson \& Cahill, supra note 18 , at 635-37.

${ }^{21}$ For a discussion of the kinds of reforms one could make to the criminal law amendment process, see Robinson, Resurrection, supra note 18, at 182-90. For examples of how studies exposing grading irrationalities can be conducted, see Paul H. Robinson, Thomas Gaeta, Matthew Majarian, Megan Schultz \& Douglas M. Weck, The Modern Irrationalities of American Criminal Codes: An Empirical Study of Offense Grading, 100 J. CRIM. L. \& CRIMINOLOGY 709 (2010); PAUL H. RoBinson ET AL., REPORT ON OFFENSE GRADING IN NEW JERSEY (2011), https://ssrn.com/abstract=1737825 [https://perma.cc/HBP8-ABRJ]; PAUl H. ROBINSON ET AL., REPORT ON OFFENSE GRADING IN PENNSYLVANIA (2010), https://ssrn.com/abstract=1527149 [https://perma.cc/969P-9JMU].
} 
unjust nature of today's popular crime-control doctrines is not a product of the community's judgments of justice but rather is seriously in conflict with them. Those doctrines are more often than not the product of crime-control strategies such as general deterrence and incapacitation of the dangerous that ignore community judgments of justice (and have been aided and abetted by many of the academics who now complain about the injustice of current law resulting from such crime-control principles). A criminal law built upon lay people's judgments of justice would be dramatically more attentive to tying criminal liability and punishment to an offender's true blameworthiness. As I have argued elsewhere, ${ }^{22}$ the theory of empirical desert, which calls for having criminal law rules reflect community shared judgments of justice, produces the best practical approximation of true justice. ${ }^{23}$

To summarize, although it may seem that community views on punishment are draconian or brutish, in reality, those views are rooted soundly in principles of proportionality and in fact seriously conflict with the harsh and disproportionate penalties found in many modern crimecontrol doctrines. That discrepancy is not the result of draconian community views but rather the result of academically inspired crimecontrol doctrines and the dysfunction of American crime politics. This brings us to our third question, which asks whether a criminal law concerned with effective crime control should care what communities think is just.

\section{Why SHOULD THE CRIMINAL LAW CARE WHAT THE COMMUNITY THINKS IS JUST?}

Given what we know about people's intuitions of justice, is there any reason that the criminal law should care about them? Should criminal law set its liability and punishment rules to track the justice judgments of the community it governs? I believe that the answer to these questions is yes. The general line of argument is this: by having criminal law adopt liability and punishment rules that track community views, it can enhance criminal law's "moral credibility" for doing justice with the community it governs, and that increased moral authority can have strong practical crime-control benefits in avoiding resistance and subversion and in gaining deference, cooperation, normative influence, and ultimately compliance.

\footnotetext{
${ }^{22}$ Paul H. Robinson, Joshua Samuel Barton \& Matthew Lister, Empirical Desert, Individual Prevention, and Limiting Retributivism: A Reply, 17 NEW CRIM. L. ReV. 312 (2014).

${ }^{23}$ Paul H. Robinson, Distributive Principles of Criminal LaW: Who Should Be Punished How MuCH? ch. 8 (2008).
} 
History certainly suggests such a dynamic, at least for dramatic levels of disrespect for the criminal law. The early Soviet criminal justice system was notoriously arbitrary and corrupt, with little or no moral credibility among the general population. Any compliance it gained was through coercion or brutality by the extensive police power. When those power centers weakened with the collapse of the Soviet Union, the crime rate increased dramatically. It was only the coercive influence of the state's threat that gave the system effect, and once that was gone, so too went its control.

But some previous empirical studies have hinted, and more recent studies have confirmed, that this same relationship between the criminal justice system's moral credibility and its ability to gain deference and compliance applies not just to extreme cases but to all-that there is a general relationship between the system's moral credibility and its ability to gain compliance. ${ }^{24}$ Even a marginal decrease in the former will produce a marginal decrease in the latter. This suggests that any system can improve its ability to gain deference and compliance by improving its reputation for doing justice and avoiding injustice.

Why should this be so? Why should undermining the criminal law's moral credibility have the effect of undermining the system's crime-control effectiveness? Let me suggest four mechanisms by which this can occur.

The forces of social influence and internalized norms are potentially enormous. A criminal law that has earned moral credibility with the people can harness these powerful social and normative forces through a variety of mechanisms. First, a criminal law with moral credibility can harness the power of stigmatization. Many people will avoid breaking the law if doing so will stigmatize them, and thereby endanger their personal and social relationships. The power of stigmatization is cheap - it does not have the cost of imprisonment, for example - and it exists even if the threat of official sanction is not present; it is enough that friends or acquaintances might learn of the misconduct. A criminal law that regularly punishes conduct seen as blameless, or at least not deserving the condemnation of criminal liability, will be unable to harness the power of stigmatization.

Second, a system that has earned moral credibility with the people also can help avoid vigilantism. People will be less likely to take matters into their own hands if they have confidence that the system is trying hard to do justice. And, as I detail elsewhere, the danger of vigilantism goes beyond those rare souls willing to "go into the streets"; it includes "shadow vigilantes" who try to force justice from a system apparently reluctant to do

\footnotetext{
${ }^{24}$ For a discussion of these issues, see ROBINSON, IJUD, supra note 1, at 176-88.
} 
it - normally law-abiding citizens and officials who see the system's failures of justice as justifying their distortion of the criminal justice process. Examples of such "vigilantism" include police "testilying" and jury nullification, which may acquit excessive use of force against aggressors. $^{25}$

Third, a reputation for moral credibility can avoid provoking the kind of resistance and subversion that we see in criminal justice systems with poor reputations. Such resistance and subversion can appear among any of the participants in the system. Do victims report offenses? Do potential witnesses come forward to help police and investigators? Do police, investigators, prosecutors, and judges follow the legal rules, or do they feel free to make up their own? In systems with trial juries, do the jurors follow their legal instructions or do they make up their own rules? Do offenders acquiesce in their liability and punishment, or do they focus instead on thinking an injustice has been done to them?

Finally, the most powerful force that comes from a criminal justice system with moral credibility is its power to shape and reinforce societal norms, and to cause people to internalize those norms. If the criminal law has earned a reputation for doing justice, then when the law criminalizes some new form of conduct or makes some conduct a more serious offense than it had previously been, the community takes this legal action as reliable evidence that the conduct really is more condemnable. ${ }^{26}$

The forces of social influence and internalized norms are potentially enormous. But if the criminal law conflicts with people's judgments of justice, that conflict will undermine law's moral credibility and thereby undermine criminal law's ability to harness these forces.

Let me show the results of just one recent study about this dynamic between the system's moral credibility, and its ability to gain compliance. Subjects were tested to determine their views on a variety of issues related to whether they would defer to the demands of the criminal law, or help investigators, or report an offense, or take criminalization to mean that the conduct really was more morally condemnable, and so on-setting a baseline for each of the specific mechanisms of potential influence described above. The subjects were then told of a variety of real-world cases in which the criminal justice system had done serious injustice or failed to do justice, not by accident but as the result of legal liability rules formally adopted with the knowledge that they would produce results of

\footnotetext{
${ }^{25}$ See generally Paul H. Robinson \& SARAh M. Robinson, THE Vigilante Echo: How FAILURES OF JUSTICE INSPIRE LAWLESSNESS (2017).

${ }^{26}$ For a more detailed discussion of these mechanisms, see RoBINSON, IJUD, supra note 1, at 15263.
} 
which the community would disapprove. After this disillusioning information, the subjects were tested again and their views on the measures of deference and compliance had all weakened. Both sets of questions used a nine-point scale where the higher the number, the greater the deference to the criminal law and willingness to comply with it. Here are the results ${ }^{27}$ :

TABlE 3: Within-SuBJECTS DisiLlusionMENT StUdy

\begin{tabular}{|c|c|c|c|}
\hline Question & $\begin{array}{c}\text { Baseline } \\
\text { Avg. }\end{array}$ & $\begin{array}{c}\text { Post-Stimu- } \\
\text { lation Avg. }\end{array}$ & Significance \\
\hline $\begin{array}{c}\text { 1. Life sentence means offense conduct must be } \\
\text { heinous }\end{array}$ & 6.46 & 5.14 & $\mathrm{p}<.001$ \\
\hline $\begin{array}{c}\text { 2. Law prohibition means posting false } \\
\text { comments must be condemnable }\end{array}$ & 6.14 & 5.76 & $\mathrm{p}<.07$ \\
\hline $\begin{array}{c}\text { 3. High sentence for financial maneuver means } \\
\text { condemnable }\end{array}$ & 5.25 & 4.63 & $\mathrm{p}<.02$ \\
\hline 4. Report removal of arrowhead & 5.93 & 5.14 & $\mathrm{p}<.01$ \\
\hline 5. Give found handgun to police & 6.66 & 5.56 & $\mathrm{p}<.001$ \\
\hline 6. Report dog violation to authorities & 5.15 & 4.59 & $\mathrm{p}<.01$ \\
\hline 7. Go back and report your mistake to gas station & 7.05 & 5.69 & $\mathrm{p}<.001$ \\
\hline 8. Go back and report your mistake to restaurant & 7.15 & 5.71 & $\mathrm{p}<.001$ \\
\hline
\end{tabular}

The graphic on the next page gives a visual display of this same information. The patterned bars show the subjects' responses before the disillusionment, and the gray bars after.

27 This table is reproduced from RoBINSON, IJUD, supra note 1, at 180. The first column lists not the full text of the questions used but rather a short-hand identification of the questions. 
FIGURE 4

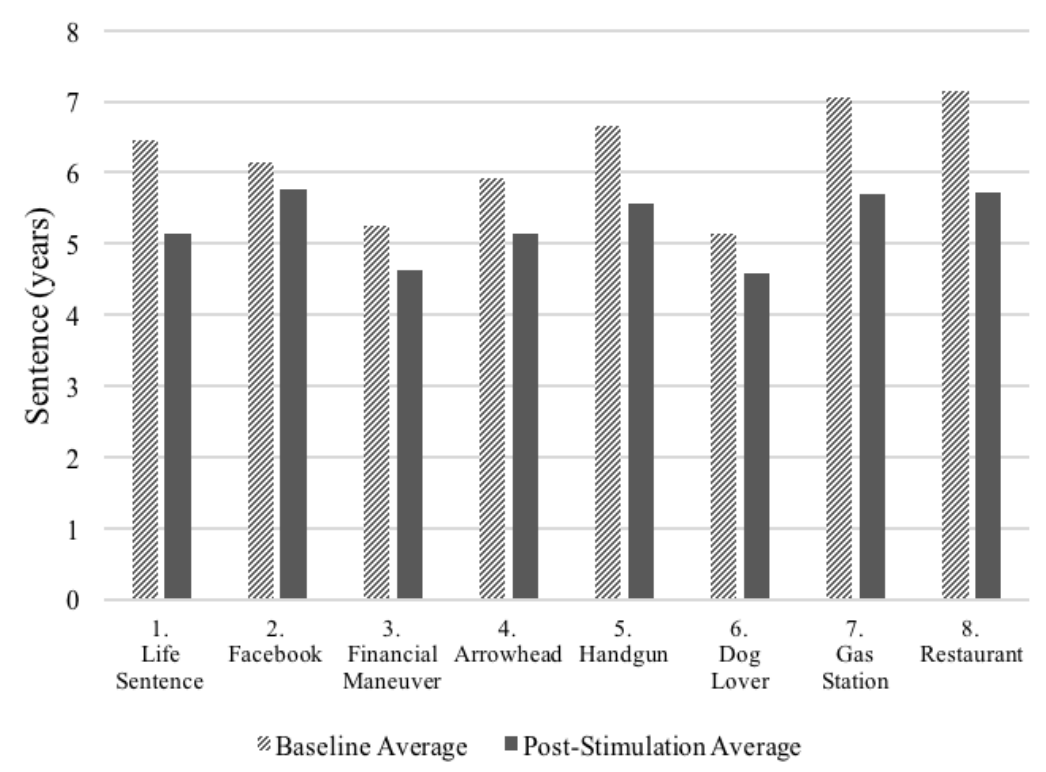

For all eight questions, deference to the criminal law decreased after the disillusioning stimuli. This is actually a quite surprising result, if you think about it. When adult subjects are tested in a study like this, they come to the study with an already-formed opinion about the moral reliability of the criminal justice system. There is a limited amount that a researcher can do in the context of a study to shift that preexisting view. But despite the fact that we can only marginally shift subjects' views of the system, we nonetheless see a corresponding downward shift in subjects' willingness to defer to the criminal justice system.

A follow-up study used a slightly different methodology. Instead of the "within-subjects design" used in the former study, it used a "betweensubjects design." That is, instead of asking the same subjects their views after being "disillusioned" about the criminal justice system, this study used separate groups. The researchers asked all subjects the same questions but did not disillusion some subjects, mildly disillusioned other subjects, and more seriously disillusioned a third group. The study found that the extent of the disillusionment determined the extent to which the subjects would defer to the criminal justice system. ${ }^{28}$

\footnotetext{
${ }^{28}$ This table is reproduced from RoBINSON, IJUD, supra note 1, at 182.
} 
TABle 4: Between-Subjects Disillusionment Study

\begin{tabular}{|c|c|c|c|}
\hline & $\begin{array}{c}\text { Baseline: No } \\
\text { Disillusionment }\end{array}$ & $\begin{array}{c}\text { Low } \\
\text { Disillusionment }\end{array}$ & $\begin{array}{c}\text { High } \\
\text { Disillusionment }\end{array}$ \\
\hline 1. Life Sentence & $6.56^{\mathrm{a}}$ & $6.59^{\mathrm{a}}$ & $5.35^{\mathrm{b}}$ \\
\hline 2. Facebook & $6.14^{\mathrm{a}}$ & $5.38^{\mathrm{b}}$ & $5.59^{\mathrm{b}}$ \\
\hline $\begin{array}{c}\text { 3. Financial } \\
\text { Maneuver }\end{array}$ & $5.25^{\mathrm{a}}$ & $5.16^{\mathrm{a}}$ & $4.34^{\mathrm{b}}$ \\
\hline 4. Arrowhead & $5.93^{\mathrm{a}}$ & $5.65^{\mathrm{a}}$ & $4.95^{\mathrm{b}}$ \\
\hline 5. Hand Gun & $6.66^{\mathrm{a}}$ & $5.40^{\mathrm{b}}$ & $4.32^{\mathrm{c}}$ \\
\hline 6. Dog Lover & $5.15^{\mathrm{a}}$ & $4.75^{\mathrm{a}, \mathrm{b}}$ & $4.43^{\mathrm{b}}$ \\
\hline 7. Gas Station & $7.05^{\mathrm{a}}$ & $6.63^{\mathrm{a}}$ & $5.63^{\mathrm{b}}$ \\
\hline 8. Restaurant & $7.15^{\mathrm{a}}$ & $6.47^{\mathrm{b}}$ & $5.84^{\mathrm{c}}$ \\
\hline
\end{tabular}

Note: The difference between two figures in the same row is statistically insignificant if they share the same letter annotation. That is, the difference between two values within the same row is statistically significant if the figures are annotated with different letters.

Another study did not collect new data but sought to determine whether the same dynamic was present in some of the large datasets of survey data previously collected by others. ${ }^{29}$ As the table below demonstrates, ${ }^{30}$ the moral credibility measure in the study explains more of the variance in the "willingness to defer" measure than any of the other measures. In fact, it is the only predictor that is statistically significant.

TABle 5: Willingness to Defer Study

\begin{tabular}{|c|c|c|}
\hline Variable & \multicolumn{2}{|c|}{ Willingness to Defer to Criminal Justice System in the Future } \\
\hline & Standardized Regression Coefficient & Significance \\
\hline Moral Credibility & .265 & $\mathrm{p}<.002$ \\
\hline Male & -.072 & $\mathrm{p}<.395$ \\
\hline Age & -.128 & $\mathrm{p}<.148$ \\
\hline White & .062 & $\mathrm{p}<.476$ \\
\hline Education & -.134 & $\mathrm{p}<.144$ \\
\hline Household Income & .017 & $\mathrm{p}<.859$ \\
\hline Married & .167 & $\mathrm{p}<.069$ \\
\hline
\end{tabular}

What the studies show is that there is a continuous relationship between a system's moral credibility and its ability to gain deference and compliance. A marginal decrease in credibility produces a marginal

\footnotetext{
29 Robinson et al., supra note 15, at 2016-23.

30 The table below is reproduced from id. at 2022.
} 
decrease in deference and compliance. This is an important conclusion because it gives every society, no matter how bad its criminal justice system's reputation, good practical reasons to improve the moral credibility of its criminal justice system. Even those systems with better reputations can improve their crime-control effectiveness by further improving their reputation for justness.

This insight is particularly important because the truth is that no criminal justice system, no matter how careful it is, can have perfect moral credibility with every member of the community. This is inevitable in part because out from the core of wrongdoing, people within a community will disagree among themselves on some matters. Thus, no matter what position the criminal code takes, it must risk alienating one group or another. But for the reasons noted above, there is still crime-control value in trying to maximize the system's moral credibility by trying to minimize the disillusioning effect of these inevitable instances of perceived deviations from desert. ${ }^{31}$ It is also worth mentioning that a criminal justice system's reputation can be influenced not only by the justness of its adjudication results but also by the fairness of its adjudication process. ${ }^{32}$

To summarize, legal rules that deviate from the community's judgments of justice are not cost-free, as has generally been assumed in the past, but rather carry a hidden cost to effective crime control. To be most effective, the criminal law should, above all else, try to build a reputation as a reliable moral authority that does justice and avoids injustice. In that

31 When faced with an issue on which there is disagreement within the community, and in trying to find the position that will alienate the fewest number of people, it will often make sense to adopt the majority view, but not always. One can imagine a situation in which a minority has very strong feelings about an issue, while a majority has less strong feelings. In some parts of the U.S., this may be the situation regarding abortion or same-sex intercourse, for example. In such situations, one may conclude that the criminal justice system's moral credibility will be least undermined by adopting the strongly held view of the significant minority rather than the less strongly held view of the majority.

32 A system and its processes seen as fair will gain greater deference and compliance than those seen as unfair. While the effect of increased "legitimacy," as Tom Tyler has labeled it, from greater procedural fairness and professionalism in policing may not have the power of the system's increased credibility in setting the liability and punishment results, it is sufficient to justify setting procedural fairness and police professionalism as important goals on the grounds of effective crime control. For further discussions on process legitimacy, see the works of Tom R. Tyler, beginning with his book Why PeOPle OBEY THE LAW (2006). For a discussion of the similarities and differences and interactions between procedural fairness and moral credibility in results, see also ROBINSON, IJUD, supra note 1, at 202-07; Josh Bowers \& Paul H. Robinson, Perceptions of Fairness and Justice: The Shared Aims and Occasional Conflicts of Legitimacy and Moral Credibility, 47 WAKE FOREST L. REV. 211 (2012). 
way, it can harness the powerful forces of social and normative influence to gain deference and compliance. ${ }^{33}$

These findings represent an important change to the classic punishment-theory debate, which has always seen two irreconcilably opposed camps. On one side are the retributivists, who urge distributing punishment in a way that does justice because they see justice as a value in itself, and therefore it needs no practical justification. On the other side are the utilitarians, who would distribute punishment so as to avoid future crime. They believe that punishment can only be justified by its future crime reduction and, therefore, typically urge the distribution of punishment to optimize general deterrence or the incapacitation of dangerous offenders.

These opposing camps would each propose a distribution of punishment to a different set of people and in different amounts, because each looks to different criteria. The retributivists, wanting to do justice, would look to an offender's moral blameworthiness. The utilitarians, who want to reduce crime, would look to what would most effectively deter and incapacitate potential offenders.

Historically, these two camps have been seen as diametrically opposed and unavoidably in conflict. The two goals - of doing justice or fighting crime - are seen as naturally in conflict and one must pick between them. But the empirical desert studies suggest that the picture is actually quite different. It may be that the best way to fight crime is to do justice.

The superiority of empirical desert as an effective crime-control strategy comes in part from the fact that an empirical-desert distribution of liability and punishment necessarily carries with it some general deterrent effect and some ability to incapacitate dangerous offenders. A just sentence can have a deterrent effect and provides an opportunity to incapacitate a dangerous offender. In fact, the only way in which those alternative distributive principles can do better than empirical desert- the only way they can provide greater deterrence or greater opportunity to incapacitateis by deviating from it - that is, by doing injustice or by failing to do justice. But it is exactly these deviations from desert that undermine the system's moral credibility and, thereby, its crime-control effectiveness. Thus, any instance of greater deterrent or incapacitation effect purchased

${ }^{33}$ For a thoughtful critique, and our response immediately following, see Donald Braman, Dan M. Kahan \& David A. Hoffman, Some Realism About Punishment Naturalism, 77 U. CHI. L. Rev. 1531 (2010); and Paul H. Robinson, Owen D. Jones \& Robert Kurzban, Realism, Punishment, and Reform, 77 U. CHI. L. REV. 1611 (2010). For another critique, see Christopher Slobogin \& Lauren BrinkleyRubinstein, Putting Desert in Its Place, 65 Stan. L. Rev. 77 (2013). Our reply was Robinson et al., Empirical Desert, supra note 22. 
by an injustice or a failure of justice can be offset by the damage such deviation does in reducing the system's moral credibility. In contrast, an empirical desert distribution, based as it is upon tracking the community's judgments of justice, can gain the crime-control benefits of moral credibility while maintaining the general deterrent and incapacitation benefits inherent in such a distribution.

It is important to note, however, that the practical crime-control power of doing justice is found in distributing criminal liability and punishment according to rules rooted in the community's judgments of justice"empirical desert"-rather than philosophers" notions of justice"deontological desert." For it is the effect of empirical desert in building the criminal law's moral credibility with the community that has the beneficial crime-control effect, and that can be achieved only by having criminal law track the community's notion of justice, not the philosophers' notion. And empirical desert is not true justice in a transcendent deontological sense.

On the other hand, the evidence suggests that, as a practical matter, empirical desert is in most respects a close approximation of deontological desert and, given the practical problems with trying to produce a criminal law based upon deontological desert, empirical desert may be the best and perhaps the only practical means of adopting a reliable approximation of deontological desert. ${ }^{34}$

Thus, criminal law that seeks to control crime should very much care about what the community thinks is just because to deviate from the community's judgments of justice - to deviate from an empirical-desert distributive principle - undermines the system's credibility and thereby its crime-control effectiveness. The greatest deference and compliance from the citizens will come from a system that commits itself to an empirical desert distribution. This brings us to our final question, which is whether it is ever justifiable to deviate from the community's judgments of justice.

\section{Should the CRIMinal LaW EVER DeViate From the COMMUNity'S SHARED JUDGMENTS OF JUSTICE?}

Even if there is value in tracking community views, should criminal law sometimes deviate from them? If so, when? That is, might one ever be justified in deciding that the criminal law should adopt a rule even though it is known to conflict with community views of justice?

\footnotetext{
${ }^{34}$ For more detailed discussion of the issue, see RoBINSON, IJUD, supra note 1, at 172-74; and Paul H. Robinson, The Role of Moral Philosophers in the Competition Between Deontological and Empirical Desert, 48 WM. \& MARY L. ReV. 1831 (2007).
} 
The answer to this question may depend upon why one is adopting a criminal law based upon community views. If it is solely out of a commitment to democratic ideals, then perhaps the community view should always prevail. If one supports adopting the community view because it generally reflects the blameworthiness of the offender rather than utilitarian crime-control programs of deterrence and incapacitation of the dangerous - that is, because it is the best practical approximation of deontological desert - then again, one might be hesitant to deviate from those community views of justice.

However, if one supports a criminal law based upon community views because of its crime-control potential in harnessing the powerful forces of social and normative influence, then logically one ought to be open to having criminal law deviate from community views if, by doing so, one could get a crime-control benefit that exceeds the crime-control cost of the deviation. The good crime-control utilitarian would presumably simply run the numbers: one could justify doing injustice or a failure of justice, as the community sees it, if such would produce such a large deterrent or incapacitative crime-control benefit as to outweigh the crime-control cost of reduced moral credibility.

However, there is reason to be skeptical that this will regularly occur. While general deterrence works in theory, research suggests that it is the exception rather than the rule that one can increase the criminal law's deterrent effect by manipulating criminal law rules. The problem is that the intended targets of the deterrence program, the potential offenders, commonly do not know of the criminal law rules that have been formulated to maximize deterrence. And even if they did know the rules, this target population frequently is irrational; they are not rational calculators who will weigh the costs and benefits of their conduct. Rather, they commonly are subject to drug abuse, alcoholism, mental illness, impulsiveness, gang influence, and so forth. And even if the potential offender knows the criminal law rule and is a rational calculator, he commonly will see the benefits of crime as outweighing the risks. This is in large part because the conviction and punishment rate for offenses is so low as to create little real risk that the planned offense will be punished. And, indeed, it is not even the actual risks of being caught and punished that matter but the risks perceived by the target audience. The target audience that regularly underestimates the risk of punishment, as is commonly the case, can destroy a deterrence program. ${ }^{35}$

\footnotetext{
${ }^{35}$ For a more detailed discussion of this issue, see ROBINSON, DISTRIBUTIVE PRINCIPLES, supra note 23 , at chs. $3-4$.
} 
With regard to deviations from community views in order to incapacitate potentially dangerous offenders, there is little doubt that such preventive detention can avoid future crime. An incapacitation distributive principle does not suffer the ineffectiveness difficulties of a general deterrence principle. However, as I have discussed in more detail elsewhere, ${ }^{36}$ the current state of the clinical sciences, such as a poor predictive ability and a serious problem of false positives, makes such a system costly both in terms of administrative costs and its intrusions on personal liberties for the false positives. Perhaps more importantly, so openly substituting pure preventive detention for criminal justice would destroy the system's moral credibility-it would make it clear that the system is simply not in the justice business - and therefore would lose access to the powerful forces of social and normative influence that moral credibility would bring.

It is perhaps no surprise, then, to see that current practice, to the extent that it tries to engage such preventive detention measures, does so while cloaking those measures as if they were criminal justice. However, the distortions required for such cloaking dramatically undermine the effectiveness of the preventive detention project. It turns out that both society and potential detainees would be better off if preventive detention, if done at all, were done openly in a civil commitment system disconnected from criminal justice.

While I see little justification for deviating from community views in order to promote effective crime control, let me suggest two situations in which deviation might be appropriate.

First, as noted above, community judgments of justice-empirical desert-are not the same as true justice in a transcendent sense-what one might call deontological desert. The community could be wrong about what constitutes justice, as we have seen in the slaveholding South in the U.S. prior to the Civil War, for example. Another example is the discriminatory treatment of women in our own history (and continuing in many societies today). We as a society may hold views today that people fifty years from now will look upon as appalling. Today's empirical desert can be wrong.

If today's community is blind to the injustice of some criminal law rule, the law ought to deviate from those community views. The problem, of course, is how are we to know this if the community fails to see the injustice. There seems no reliable mechanism by which the many claims of injustice can be screened to determine those few that might stand the test of

\footnotetext{
${ }^{36}$ For more detailed discussion of these issues, see id. at ch. 6; and Paul H. Robinson, Punishing Dangerousness: Cloaking Preventive Detention as Criminal Justice, 114 HARV. L. REV. 1429 (2001).
} 
time. What one can say, however, is that a society ought to be constantly vigilant in testing its current criminal law to determine whether its rules are producing unappreciated injustices.

One final reason to deviate from community views is likely to be more common, and more important. It is sometimes the case that government or social leaders can see a need to change community norms regarding a particular practice or conduct. In the United States, for example, over the past several decades people's views have shifted on the condemnability of such things as insider trading, domestic violence, drunk driving, downloading music without a license, and date rape. Social and political reformers have seen these shifts in public attitudes as important to the creation of a better society. But if criminal law is always to follow the community's current judgments of justice, then how can law play a role in helping to bring changes in community views? If empirical desert is the distributive principle, it would seem to condemn criminal law to be always a follower of public opinion, never a leader.

Certainly, if community views change, then criminal law can and should change with it. But must criminal law always be a follower? Can criminal law sometimes be used to help bring about changes in the community's judgments about what is condemnable? The criminal law certainly could be effective in doing this. By more broadly criminalizing certain conduct or by increasing the penalties assigned to it, the criminal law can signal to citizens that they ought to think of such conduct as being more condemnable than they had previously thought it.

But using criminal law to change community views creates complications for empirical desert. ${ }^{37}$ If empirical desert is attractive as a distributive principle because, by tracking community views, it can earn a reputation as being a reliable moral authority and can inspire greater deference to its commands and greater internalization of its norms,${ }^{38}$ then if the law conflicts with community views - by being out in front of public views - it can lose its crime-control effectiveness because it might come to be seen as an unreliable and unjust distributor of punishment.

Thus, whenever criminal law seeks to be a leader of community views, it must worry that such deviation risks undermining its moral credibility. American Prohibition in the 1920s illustrates the problem. Because of a combination of political forces, a constitutional amendment was passed that prohibited the sale of alcohol in the United States, even though only a minority of Americans actually supported such

\footnotetext{
37 See RoBInson, IJUD, supra note 1, at 70-82.

38 See Robinson, DistRIBUtive PRINCIPLES, supra note 23, at 175-212.
} 
criminalization. The law was thus seen by most citizens as criminalizing conduct that was not sufficiently condemnable to be treated as criminal.

The result was an alcohol ban that was famously ignored. Americans continued to make and drink alcohol, which brought them into conflict with the criminal law. What is most interesting in this historical episode is that citizens increasingly ignored not only the criminal law ban on alcohol but also criminal law's other prohibitions. Crime rates increased, even for offenses unrelated to the use, sale, or manufacture of alcohol. The criminal law's loss of moral credibility with the community undermined its crimecontrol effectiveness generally.

This is exactly as the reasoning underlying empirical desert would predict. As the criminal law pressed its prohibition on alcohol despite the fact that a majority of the community did not see alcohol as sufficiently condemnable to be criminal, the criminal law's reputation with the community suffered. People could reason that if the criminal law could be so wrong about the condemnability of alcohol use, perhaps it was also wrong about some of the other things that it prohibits. In 1933, Prohibition was repealed and the criminal law began to heal its injured reputation. ${ }^{39}$

Prohibition nicely illustrates the dangers for any social reformer who seeks to use criminal law to change community views. If the reformer seeks to persuade people that certain conduct, such as drunk driving, is really much more condemnable than they thought, by broadening the prohibition and the penalties for drunk driving, the legal reform might well be able to influence community views, and shift them, to have people see drunk driving as more condemnable. And as the community view shifts, the conflict between community views and the criminal law disappears, and with it disappears the danger that a code-community conflict will undermine the criminal law's moral credibility. On the other hand, there is the danger that the criminal law's attempt to change community views will be unsuccessful, as it was in Prohibition. And when that happens, the conflict between community views and the criminal law does not go away but continues, and continues to undermine the law's credibility.

Ironically, it is social reformers more than any other group who should be most anxious to develop and maintain the system's moral credibility, because it is that credibility that gives criminal law the power to shift societal norms. If law lacks moral authority, it can do nothing to change people's views. Thus, social reformers ought to consider a general approach of this sort: In regard to most issues, have criminal law maximize its moral credibility with the community by carefully following existing

\footnotetext{
${ }^{39}$ For a detailed discussion of the Prohibition, see ROBINSON, PIRATES, supra note 12, at ch. 8.
} 
community views so as to build its reputation as a reliable moral authority. Once that reputation has been established-once the criminal law has earned "moral credibility chips" with the community-reformers can carefully and selectively "spend" those chips by having law criminalize or punish more severely the conduct about which it seeks to change community views. The legal change will signal to the community that they should see the conduct as more condemnable, and the law's credibility will induce citizens to accept and internalize this view. If the reform is successful in changing people's views, then the gap between the criminal law and community views will disappear and the reform can be consolidated. If the effort is not successful in changing people's views, then the effort should be abandoned before the conflict between community views and the criminal law brings the criminal law into disrepute.

To be clear, there is no problem with social reformers seeking to change community views through means other than criminal law reform. There is no damage to criminal law-no undermining of its moral credibility - if social reformers use mechanisms such as advertising, education, governmental proclamation, or any other mechanism to influence people.

Let me offer one last piece of advice to social reformers who are hoping to change community views on the condemnability of specific conduct: not all community judgments about what should be criminal can be effectively altered. ${ }^{40}$ Some judgments are so deep-seated as to be essentially immune to attempts to change them. This is probably true of people's judgments that serious wrongdoing should be condemned and punished and people's view that the core of criminality-physical aggression, taking of property without consent, and deceit in exchanges - is condemnable. As noted above, there is good evidence to suggest that people's judgments on such matters are the product of a partially innate predisposition as a result of evolutionary development; they are not something that can be educated or coerced out of people's thinking. ${ }^{41}$

The immutability of people's judgments about the core of wrongdoing does provide an interesting insight that reformers might usefully exploit: reformers can increase their ability to have people see some conduct as deservedly criminal if they can build up in people's minds the strength of the analogy between that conduct and the core of wrongdoing. For example, there has been a major effort by companies and artists who produce music, movies, or books to persuade people that they should not

\footnotetext{
40 See RoBINSON, IJUD, supra note 1, at 74-76.

41 See RobInSOn, IJUD, supra note 1, at ch. 3.
} 
download such materials without a proper license. People used to think of such downloading as being primarily a technical violation of copyright law, not truly condemnable conduct. But the public campaign to change those views has been somewhat successful, and the most successful part of it has been a publicity campaign that seeks to build the analogy to core wrongdoing with images of a musician having money taken from his pocket - an attempt to visually build the analogy between downloading without a license and physical theft.

To summarize, one can justify deviations from community views when using criminal law to help change societal norms, but such use is possible only if a system has earned moral credibility by generally adhering to empirical desert as a distributive principle and is wise only if used occasionally, selectively, and carefully.

\section{CONCLUSION}

Distributing criminal liability and punishment according to rules based upon the community's judgments of justice can be attractive for purely democratic reasons. It also may be attractive because an "empirical desert" distribution may be the most feasible best approximation of "deontological desert"-justice in some broader transcendent sense as moral philosophers would define it. But what may be most striking about empirical desert as a distributive principle is that it ought also to be attractive to crime-control utilitarians. Because empirical desert will, essentially by definition, be seen as the most just of all distributive principles, it has the ability to harness the powerful forces of social and normative influence.

Having earned such moral credibility, the criminal justice system can reduce resistance and subversion; can increase assistance, cooperation, and acquiescence; can engage the powerful yet inexpensive mechanism of stigmatization; can reduce the likelihood of vigilantism; can gain greater compliance in borderline cases of conduct whose condemnability is unsettled; and, perhaps most importantly, can increase its ability to have community members internalize its norms.

But the proper place of community views is in the creation of legal rules, not in the adjudication of individual cases. Lay judgments in individual cases can be distorted by biases, consciously or otherwise, that even the laypersons themselves would agree ought to play no role in distributing punishment. These biases can be isolated when social psychologists test lay judgments of justice, but cannot be effectively controlled when the community is asked to directly judge an individual case. Further, a system based upon a codified set of liability and punishment rules will produce greater uniformity in application and, 
therefore, greater moral credibility in the long term, than a system of ad hoc adjudication.

Once the criminal law has earned a reputation as a reliable moral authority, it can "spend" those moral credibility "chips" in trying to lead rather than follow community views on selective issues. But reformers must be ready to pull back if the reform efforts are not successful, in order to avoid damaging its reputation for justice and thereby endangering its effectiveness as an engine of reform in the future. Reformers should also avoid wasting their hard-earned chips by spending them on attempts to modify community views that are simply not malleable. It would be a hopeless and wasteful exercise, for example, to try to persuade the community that they should not want serious wrongdoing to be punished, as many modern punishment abolitionists seek to do.

Social reformers are encouraged to use any number of other institutions of social influence to shape community views, including schools, social media, religious organizations, community activism, and the political process. And whatever community judgments of justice are changed by these processes, the criminal law should be careful to follow if it is to maintain its reputation for justness.

To conclude, the available evidence suggests not that community judgments of justice are an endless collection of individual disagreements but that there is strong agreement on a core of issues regarding the relative blameworthiness of a wide range of offenses and offenders. And those shared judgments of justice are not brutish and draconian, but rather stand in stark contrast to the brutish and draconian measures created by the modern coercive crime-control doctrines of general deterrence and incapacitation of the dangerous, which disconnect criminal law from the constraints of justice. That disconnection, in the name of effective crime control, reflects a failure to appreciate the crime-control cost of criminal law's conflicts with community judgments of justice. Such evidence should influence criminal law reformers to attempt to firmly connect the criminal law to community judgments of justice. 
N O R T H W ESTER N U N IVER S T Y LA W R E V I E W 